\title{
Economic Forces and Firm Stock Returns Volatility: Role of Firm Features
}

\author{
Muhammad Saqib Bashir Butt ${ }^{1}$, Hasniza Mohd Taib ${ }^{1}$ \\ ${ }^{1}$ School of Economics, Finance and Banking, College of Banking, Universiti Utara Malaysia, \\ Sintok, 06010, Kedah State, Malaysia \\ Email: msaqib101@yahoo.com
}

\begin{abstract}
Stock market volatility is always been a major concern for investors, regulators, policy makers and academicians. Unfortunately, firm level volatility has not been given the due attention. The studies dealing with the firm level volatility are scarce. Moreover, a common assumption of homogenous nature of firms is used in the aggregate stock market analysis, sectoral level analysis and even in a firm level analysis. This homogenous assumption was objected by several researchers and suggested that firms are heterogeneous even in a narrowly defined sector. Furthermore, firms are different from each other because of possessing different characteristics. Based on that firm's response to macroeconomic changes would not be the same. Hence, the hypothesis testing ignoring this fact could be spurious. This study proposes five categories in which firms can be classified, such as firm age, firm size, firm nature of business, firm trading nature and the sectoral location of the firm. This study proposes to examine the linkages between the macro economic factors and the firm level stock returns volatility considering the given firm features. It is expected from the empirical testing that the macroeconomic factors effect firm stock returns volatility belonging to different firm features differently, both in terms of magnitude and sign.
\end{abstract}

Keywords: economic forces, firm volatility, firm features

\section{Background}

Arbitrage pricing theory proposed by Ross (1976) as an alternative to the capital asset pricing model motivates the researchers to explore the dynamic linkages between the macroeconomic forces and stock prices. The financial press segregates the empirical literature on economic factors and stock return into two clusters. The first strand of the literature deals with economic factors and stock returns while the second strand 
highlights the relationship between the economic factors and stock returns volatility. This study will focus on the second strand.

Financial market volatility is of greater concern for investors, regulators, policymakers, and academicians. The persistent increase in financial market volatility may cause capital flight and the whole economy can be distressed. In recent times the world financial markets are well integrated, the volatility spill over may cause a contagion effect. So the financial market volatility can be disastrous not only for a single economy but it may have serious repercussions for the world economy. The adverse effects of stock market volatility on the smooth functioning of the stock markets as well as on the domestic economy and other economies can be witnessed through the history of stock market crashes. For instance, in a more recent US Financial Crisis, 2008, households lost 3.4 trillion dollars in real estate and value of equity holdings drop by 7.4 trillion dollars between July 2008 to March 2009. The US banks total writedowns were over one trillion dollars. The American economy lost 650 billion dollars in GDP and people lost 5.5 million jobs (see in detail, Swagel, 2010). Due to the high significance of financial markets in world economies, it is much more important to have a clear understanding of the factors that are affecting the stock market volatility. In the earlier studies, Officer (1973) relate the aggregate stock market volatility with the business cycle represented by changes in industrial production. Black (1976) documented the evidence of leverage effect in the predictability of stock market volatility. Similarly, Christie (1982) identified the positive influence of financial leverage and the interest rate on aggregate stock market volatility. Further, suggesting the existence of many other factors that might affect the stock market volatility. Keeping this view in mind, Schwert (1989) investigated the relationship of a large number of factors comprised of real and nominal macroeconomic factors, financial leverage, economic activity and trading activity with the US stock market volatility. The results presented weak evidence of predictability of stocks and bonds return volatility with the macroeconomic volatility. In addition, a strong relationship was discovered between financial leverage and stock market volatility and a positive relationship was found between the trading activity and the stock volatility. Afterward, 
several studies examined the linkages between the macroeconomic factors and aggregate stock market volatility in the developed economy (see, for example,(Baillie \& DeGennaro, 1990; Beltratti \& Morana, 2006; Choudhry, Papadimitriou, \& Shabi, 2016; Engle, Ghysels, \& Sohn, 2013; French, Schwert, \& Stambaugh, 1987; Liljeblom \& Stenius, 1997; Poon \& Taylor, 1991) and in the developing economies as well (see for example; (Adjasi, 2009; Girardin \& Joyeux, 2013; Oseni \& Nwosa, 2011). These studies used an index approach to analyze the stock market volatility with the underlying assumption of homogeneous nature of firms. This approach is criticized by several researchers.

The aggregate stock market volatility analysis cannot be ignored, and it has its own significance in the literature but several research studies challenged the results of aggregate market analysis and supported the firm level analysis in this regard. It is argued that the firms that are making up the market are heterogeneous in nature because of owning unique characteristics whereas the index approach either stock market index or a sectoral index assumes the homogeneous nature of firms. The results obtained on the basis of the index approach are then spurious. Further, it is believed that since firms are heterogeneous in nature their response would not be the same against the macroeconomic changes in the economy (see, for example, Chou, Ho, \& Ko, 2012; Chun, J.-W. Kim, \& R. Morck, 2009; Comin \& Mulani, 2006; Davis \& Kahn, 2008; Narayan \& Sharma, 2011; Sharma \& Narayan, 2014; Sharma, Narayan, \& Zheng, 2014). Moreover, in recent studies, a divergent behavior was recognized between the aggregate stock market volatility and the firm level volatility (see, for example, Campbell, Lettau, Malkiel, \& Xu, 2001; Sharma et al., 2014; Xu \& Malkiel, 2003). These studies assert the necessity of examining the firm level volatility with respect to firm characteristics to have a clear understanding of firms behavior against macroeconomic sensitivity. This study will be helpful to the investors, regulators, policymakers for better decision making and as well as for the academicians to understand the true behavior of firms.

To strengthen the arguments further some theoretical justifications on firm-level volatility and firm features /characteristics are presented below: 


\section{Motivation for firm-level volatility Analysis}

First, the volatility of stock returns is extensively examined at the aggregate market level and to some extent at the sectoral level but unfortunately, the firm-level volatility was not given much attention. The studies on the firm level volatility are scarce up till now (see, for example, Campbell, Lettau, Malkiel, \& Xu, 2001; Khan et al, 2014; Sharma et al., 2014).

Second, the index approach in stock market analysis or even in a sectoral level analysis considers firms/sectors are homogeneous. This assumption has some limitations and several researchers suggested to study the stock returns volatility by relaxing this assumption and considering the firms are heterogeneous in nature because of their unique characteristics.(see, for example, Bernard, Jensen, \& Lawrence, 1995; H. Chun, J.-W. Kim, \& R. Morck, 2009; Melitz \& Redding, 2012; Narayan \& Sharma, 2011). This implies that the firm's response towards any new information or any change in the macroeconomic forces will be different based on their specific features/characteristics. However, Hanson, Pesaran, and Schuermann (2008) emphasized to consider the heterogeneity at the firm level analysis, otherwise, this negligence might lead to the ambiguous effect on the portfolio risk. Furthermore, Chun, Kim, Morck, and Yeung (2008) discovered that the increase in heterogeneous performance among the firms is cancelled out at the aggregate level. It implies that the aggregate analysis cannot be generalizable (Ewing, Kruse, \& Thompson, 2005). While considering the importance of firm characteristics, Buch, Döpke, and Strotmann (2009) explained the increase or decrease in the firm level volatility is due to the heterogeneous responses of the firms on the basis of their unique characteristics such as the exporting firms have different exposure and respond differently to the exogenous shocks than the domestic firms and in the same way a different response would be expected from the small and large firms.

Third, several studies found a profound diverging trend in firm-level volatility and the aggregate level volatility in recent times. (see, for example,Campbell et al., 2001; Comin, 2000; Comin \& Mulani, 2003; Comin \& Mulani, 2006; Sharma et al., 2014; Xu \& Malkiel, 2003). It was surprising that the aggregate stock market volatility 
was stable overtimes but the firm level volatility was exhibiting a positive increasing trend during the same time period. This puzzle was investigated in many previous research studies but it is still inconclusive. For example, Campbell et al. (2001) proposed that the diverging trend in volatility is due to the decreasing trend in the association among the firm stock returns. However, Kahn, McConnell, and PerezQuiros (2001) suggested the decline in macroeconomic activity is due to the improvement in the inventory management systems at the firm level but this argument cannot be approved because if it is so then it has to reduce the firm level volatility as well. Davis and Kahn (2008) made a similar argument that better inventory control is the reason for the decline in the aggregate market volatility. Another stream of studies related the decline in aggregate market volatility with the effective monetary policy (see, for example,(Boivin \& Giannoni, 2002; Galı, López-Salido, \& Vallés, 2003; Justiniano \& Primiceri, 2006; Sims \& Zha, 2002). However, Blanchard and Simon (2001) associated the diverging trend with the decline in output volatility while denying the role of monetary policy and financial market improvements. Moreover, Comin and Mulani (2006) related the issue with the shift in investments from disembodied (such as new accounting practices, mass production, or the use of alternative source of energy in the plant) to embodied (such as patentable innovations) innovations denying the effect of monetary policy introduced by Federal Reserve System(FED) and the improvements in the inventory management systems. Further suggesting that the research and development has a minor impact. In a similar study, Comin and Mulani (2009) related the increase in firm volatility and decline in aggregate market volatility with the increase in research and development. Comin and Philippon (2006) proposed that the increase in firm-level volatility is due to more competition among the firms in the product market. Chun, Kim, and Morck (2009) related the issue with the increase in heterogeneity among the firms. Further indicating that the young and small firms are riskier than the old and established firms, as their substantial existence in any industry will lead to the higher firm-level volatility in several performance measures. Thesmar and Thoenig (2011) related the increase firm volatility with the increase in international capital market integration and stock market participation. Further suggesting at the 
micro level that the increase in the ownership diversification leads to an increase in the firm volatility.

Fourth, the implicit assumption of the asset pricing models is that the idiosyncratic risk is eliminated through a well-diversified portfolio while the systematic risk is the only component that can be compensated. Whereas many investors do not follow the financial theories in constructing a large portfolio. Campbell et al. (2001) argued that these investors are affected by the shifts in industry level volatility and the idiosyncratic volatility in the same way as they are affected by the shift in market volatility. Secondly, the investors making up the portfolio are unaware of the level of idiosyncratic volatility of these stocks. Merton (1987) suggested that the increase in idiosyncratic risk will lead to increase in the expected returns while Shleifer and Vishny (1997) posted a counter-argument that the increase in idiosyncratic risk will decrease the stock returns because stocks are irrationally priced and the idiosyncratic risk prevents the arbitrageurs to arbitrage. Furthermore, the arbitrageurs are dependent on the resources of few investors and these investors are interested in total risk and not only in the systematic risk. Hence, it is inappropriate to consider the systematic risk as to the only determinant of pricing. However, Constantinides and Duffie (1996) also emphasizing to consider the firm level risk because its unawareness can affect the estimation of expected excess returns either resulting in overestimation or underestimation.

\section{Motivation for Firm Features}

There are several firm features but five prominent features namely; firm size. firm age, firm nature of business, firm trading nature and sectoral location of firms are discussed below. These firm features are used in the thesis to uncover the effect of macroeconomic factors on stock returns volatility. These firm features/ characteristics have both theoretical and practical significance. Its significance further magnifies in the context of the US financial market.

\section{A. Firm Size}

According to Chen and Hambrick (1995) firm size can be defined " in terms of sheer organizational size or in terms of its industry market share”. However, market 
capitalization is extensively used in the literature to determine the firm size (Francis, Mougoué, \& Panchenko, 2010; Sharma et al., 2014). Based on market capitalization, firms can be categorized from small to large. In earlier studies, Banz (1981) and Reinganum (1981) identified different risk-return behaviour in firms due to different firm sizes. Moreover, there is an extensive literature drawing attention towards the heterogeneous behaviour of firms to the market-wide shocks contingent on firm size. The divergent behaviour is expected because of different potentialities of firms associated with the difference in firm sizes. Despite agreeing on the mixed behaviour, the research studies are still inconclusive in predicting the behaviour of small and large firms to the external shocks.

In this respect, Chen and Hambrick (1995) argued that small firms have more propensity for action than large firms due to several reasons. For instance, small firms have a lack of resources, so they are in a constant threat from their large rivals. It is necessary for the small firms to take aggressive actions so that they not only be competitive in the market but also expand their business. These firms are always in a war with their large competitors making them vigilant in the market. On the other hand, large firms are overconfident because of owning large resources and experienced management. So, these firms mostly ignore their small competitors. In addition, large firms have a complex structure and bureaucratic style of work that limits their competitive actionability. While small firms due to their simple structure and targeting a niche, allows them to quickly initiate a competitive move to create a greater impact in the market.

Vossen (1998) gives a detailed theoretical overview of small and large firms. Several differences between small and large firms are identified. Such as the small firms are flexible, have quick decision-making ability, are risk takers, have motivated labour and management, are quick in responding to changing market requirements, have effective internal communication network, have R\&D efficiency and ability to learn fast. While large firms are formal, more ability to control complex organizations, are risk-averse, can diversify risk through portfolio of products, have specialized labour, have economies of scale and scope in $\mathrm{R} \& \mathrm{D}$, have more financial resources to establish 
large R\&D laboratory, have access to external financing, are able to diversify funds, have more capacity to absorb new technology, and are dominant in existing products. These characteristics differentiate them significantly in terms of innovations. It is argued that small firms and large firm's innovations varied because of their different capabilities.

Moreover, some other researchers are of the view that large firms perform better than small firms because of several reasons. For example, Lucas Jr (1978) suggested that small firms' management is less capable than large firms. In addition, small firms are more dependent on the local and regional markets than the large and old firms, whereas large and old firms also operate outside the regions (Wilson \& Gorb, 1983). This will decrease their ability to earn higher profits. Investors are less informed about the small firms than the large firms because large firms gained more attention in the financial press and from credit rating agencies. Consequently, it can generate information asymmetry between small firms and potential investors. So small firms face moral hazard and agency cost in acquiring funds from the public (Petersen \& Rajan, 1994). Hence, to support profitable investments, small firms have less ability to generate higher funds than large firms (Berger \& Udell, 1995). Since small firms are financially constrained therefore firms have to spend most of the time in risk management activities (Vickery, 2008). Higher monitoring cost forces the small firms to pay the higher cost on the funds than the large firms (Faulkender \& Petersen, 2006; Rostamkalaei \& Freel, 2016). On the regulation part, small firms must faceless regulations (i.e., hygiene and safety rules, the mandatory election of employee's representative, etc.) than the large firms. More so, the compliance cost is so high small firms are exempted from these rules, allowing them to be more competitive in the market (Gourio \& Roys, 2014).

The theories on small firms and large firms are explaining mixed behaviour. But one can draw a conclusion that these two features of firms have significant differences in terms of administrative qualities, business structure, business strategies, resources, $R \& D$ investments and growth opportunities, financing, attitude toward risk, access to the tangible and financial market and many more. Due to so many differences, some 
argue that the small firms' exposure to the risk is also different from the large firms. The small firms are more exposed to the local factors than the large firms, while large firms are more exposed to the systematic factors (Brown \& Kapadia, 2007; Elyasiani, Mansur, \& Pagano, 2007). On the basis of these differences, it is expected that the firms, the behaviour will be different with respect to their sizes against the changes in macroeconomic factors.

\section{B. Firm Age}

Age of any being can be defined as the length of time since it comes into existence. In the case of firms, C. F. Loderer and Waelchli (2010) defined firms as the "corporations observed in practice". The age of firms is then measured from the date when the firm becomes a legal entity. Further, supporting this argument, Ilaboya and Ohiokha (2016) suggested that the date of incorporation is more relevant in determining age as it becomes a legal entity. However, Shumway (2001) argued that " a firm can be incorporated as a small speculative concern or as a large holding company, making the firm's age since incorporation less economically meaningful than its age since listing".

Evans (1987) explained that the firm age is an important determinant of firm dynamics. As firms age starts from their birth or listing with the stock exchange and it goes till the death of the organization, some firms survive more than the others. This depends on how they move in the different stages of their age. Organizational theories suggest that the firms need continuous improvement in the organizational structure, management style, technological advancements, social networking, employees' skills, products, and in innovation activities for their growth and survival in the market. However, it is observed by many researchers that when the firms get older they become more rigid and have inertia which hinders their growth, productivity, profitability, and chances of survival in the market (see for example,Glancey, 1998; Hannan \& Freeman, 1984; C. Loderer, Neusser, \& Waelchli, 2008; C. F. Loderer \& Waelchli, 2010).

Hannan and Freeman (1984) explained that the organizational inertia is not about the organizations do not change but it is about the speed of organizations response to the environmental changes. So, the high inertia in organization structure depends on the speed of reorganization in case of environmental changes. The firms of different 
ages do not have the same ability to respond reflecting at different degrees of inertia. Hence, it can be implied that the firms' volatility varies with age.

However, it is also recognized in the literature that profitability decline as the firms grows older. C. F. Loderer and Waelchli (2010) explained that this relationship may exist because of organizational rigidity and rent-seeking behavior of older firms. Since older firms are less efficient, reduced $R \& D$ and capital investment, obsolete assets, slower growth rate, and higher fixed cost exhibit high organizational rigidity. Further, older firms are less capable to solve the collective action problems due to larger boards, poor corporate governance and higher CEO compensation exhibiting rentseeking behavior. Further supporting the argument of organizational rigidity in the older firm, de Figueiredo Jr, Rawley, and Rider (2015) identified three sources of rigidity namely, internal political frictions, exchange partner reservations and implementation cost which may increase with the age consequently causing older firms to underperform.

On the contrary, Bahk and Gort (1993) argued that firms learn by doing. As the firms mature, they can invest in human capital, training programs, and research and development. Further, they can improve production processes, product quality, and product innovations. This implies that firm performance improves with age and experience. Coad, Segarra, and Teruel (2013) argued that firms' performance can be improved with age and deteriorate as well. It was observed that older firms improve with age as these firms are large, having lower debt ratios, higher equity ratios, higher profits, and steady growth in production. In addition, these firms have more ability to convert sales growth into profits and productivity growth. On the contrary, the firm performance deteriorates with age as these firms have lower expected sales growth, lower profitability, and productivity and show less ability to transform employment growth into sales, profit, and productivity growth. The innovations also help the firm to achieve a competitive edge in the market. Drnevich, Marino, and Withers (2011) theoretically explain that young and old firms are different in producing innovations. When both firms have innovation capabilities, in that case, the old firms are more likely to produce innovations than their young counterparts. While in the absence of 
innovation capabilities then young firms are more probably to produce innovation than the old firms.

However, it is also noted that young firms have deficiencies as compared to older firms in resources and capabilities, general management skills, financial management skills and market development skills that may lead them to the failure (Thornhill \& Amit, 2003). Since the younger firms have multiple deficiencies, investors are not certain about their performance and survival. The uncertainty is very high in younger firms than the older firms that may increase the volatility in the younger firms (Pastor \& Veronesi, 2003). Moreover, younger firms have a lack of internal resources to fund investments, due to uncertainty and information asymmetry these firms have to rely more on debt financing than equity financing. While older firms have large internal funds from retained earnings and more access to the equity market that decreases the dependence on debt financing. The financing cost for young firms is higher than the old firms. In addition, the capital structure or debt to equity ratio of young firms will be high as compared to old firms. So the debt to equity ratio and the cost of financing varies with the life cycle of the firm (Pfaffermayr, Stöckl, \& Winner, 2013). This implies that the risk level of the younger firms would be higher than the older firms and increase the chances of bankruptcy among young firms. Furthermore, young firms create enormous jobs, but these firms are highly volatile. So job creation and destruction is also very high in young firms than the old ones (Haltiwanger, Jarmin, \& Miranda, 2013). Further, Young and small firms are more exposed to the business cycle shocks (Fort, Haltiwanger, Jarmin, \& Miranda, 2013).

In light of the above arguments, it can be concluded that young and old firms are completely different. The theories explaining firm behaviour are mixed. It is expected that young and old firms' response to macroeconomic changes would be different. Hence, an empirical comprehensive firm-level study in this regard may provide a solution to these questions.

\section{Firm Nature of Business (Financial and Non-Financial)}

It is widely recognized that financial firms or institutions (depository and nondepository institutions) are different from the non-financial firms because of their 
intermediary role in the economy. These institutions provide a channel through which the funds flow from saving surplus unit to the saving deficit unit in any economy. These units might be individuals, businesses and governments. More precisely, the FIs have an influential role in the administration of payment mechanism, sectoral credit allocation and transmission of monetary policy(Saunders, Cornett, \& McGraw, 2006). These unique features require a separate regulatory body so that the financial institutions must be monitored tightly otherwise the failure of financial institutions may have a drastic impact on the economy. Even a single large financial institution failure can trigger a financial crisis in the economy. Whereas the failure of the non-financial firm or some firms may not have the same impact. Kaufman (1994) argued that the failure of one bank or more banks can not only create a failure to the other banks or the whole banking system but it will be so severe that it can go beyond the entire financial system and the macroeconomy as well. So if this is not controlled at the beginning it might affect the whole economy, as it was observed in the US financial crisis of 20072008 (Zhou, 2009). The US authorities announced a bailout package for the AIG, sensing that the failure of this large insurance conglomerate will have some serious repercussions for the entire economy (Tarashev, Borio, \& Tsatsaronis, 2009). Therefore, FIs are more likely to exhibit a different response to the shocks as compared to the non-financial firms.

Moreover, in recent times the world economies have witnessed the revolutionary changes in the financial markets and institutions (see, for example, Acemoglu, Ozdaglar, \& Tahbaz-Salehi, 2013; Allen \& Gale, 2000; Allen \& Santomero, 1997; Merton, 1995). Furthermore, Acemoglu et al. (2013) pointed out that the immense increase in interconnectedness among financial institutions, a negative shock beyond a certain point can bring the whole financial system at stake.

The arguments presented on the firm nature of business explain the different sensitivities of financial and non-financial firms to the macroeconomic sensitivities. In light of these arguments, it is necessary to disaggregate the firms on the basis of financial and non-financial firms to empirically verify the differences in linkages between macroeconomic factors and stock returns volatility. 


\section{Firm Trading Nature (Exporting Vs Non-Exporting)}

It has been widely recognized that the exporting firms are different from nonexporting firms on various dimensions. Such as exporting firms are larger in size, more capital intensive and technology intensive and skill intensive, more productive and high performing, and pay higher wages. There are some other benefits that can be attributable to the exporting firms such as faster growth of shipping and productivity, diversification of risk, increased innovation and improve survival chances. On the opposite side, there is some additional cost on selling products must be borne by the exporting firms. These costs include transportation, expense on establishing a distributional channel, and customization of products according to the foreign requirements (Bernard \& Jensen, 1999; Bernard et al., 1995; Hagemejer \& Kolasa, 2011).

However, the cost associated with the exports is not easy to bear by all the firms in the market. Therefore, all firms cannot enter into the exporting business. There is an argument that the firms with a comparative productive advantage over the other firms could bear the additional cost prior to start exporting. This behaviour of exporting firms is referred to as "self- selection". This also implies that exporting firms with high productivity have more chance to survive than non-exporting firms with low productivity. Others argue that the firms' productivity will increase after entering into the export market. This phenomenon is referred to as "Learning by exporting". (Bernard, Jensen, Redding, \& Schott, 2007). The empirical studies found mixed results on the "self-selection" and "learning by exporting" hypothesis (Augier \& Dovis, 2013; Delgado, Farinas, \& Ruano, 2002; Wagner, 2007). Further, Aw, Roberts, and Winston (2007) discussed that the productivity of exporting firms depends on the firm's ability to acquire and adopt new technologies. As the firms are heterogeneous in in-house capabilities they might differ in assimilating new technologies. Moreover, Cassiman, Golovko, and Martínez-Ros (2010) argued that one of the reason for the exporting firms to be more productive is the innovation activities. Further suggesting that the product innovation rather than the process innovation is most important for the productivity and pave the way to enter the export market. While Chaney (2016) argued that it is the 
liquidity constraint that does not allow most of the firms to export. So, the firms that can generate higher liquidity through sales or inherited large liquidity are more probable to export. However, in any case, it explains that the exporting firms are more productive, more financially sound and innovative than the non-exporting firms. Hence exporting firms have more ability to sustain adverse shocks than the non-exporting firms and it increases the chances of their survival. These features make them attractive to investors.

However, from the theoretical perspective, it is still inconclusive whether export increases firm-level volatility or decreases firm-level volatility. Whereas the exporting and non-exporting firm's distinct features allow them to differ in volatility as two nature of businesses are either exposed to different types of shocks or respond differently to these shocks. Amiti and Weinstein (2009) argued that exporting firms are more prone to financial shocks as these firms are heavily dependent on the banks for working capital, risk management, and export guarantees. When the banks are affected by the shocks they limit trade credit and consequently affect the exports more than the domestic sales. Buch et al. (2009) argued that exporting firms might increase volatility when foreign shocks are larger than domestic shocks. But due to the lower correlation between domestic and foreign shocks, this effect can be counterbalanced as the exporting firms' sales are not cantered to one location and distributed across several markets, the diversification effect might reduce volatility. While Vannoorenberghe (2012) explained the sales volatility in view of firm heterogeneity, suggesting that exporting itself is a volatile activity and the difference in volatility between exporting and non-exporting depends on the exports share. Further explaining the difference in the behaviour of exporting and non-exporting firms to face shock, presented a similar argument that in the case of imperfect correlation between the domestic and foreign shocks, the exporting firms can substitute sales between the domestic and foreign market. Moreover, it is also asserted that firm-level analysis in particular firm behaviour was ignored in previous studies. Riaño (2011) argued that the export increases the sale volatility because of the sunk cost that is initially required to enter the export market and the fixed participation cost a firm has to maintain every period to be 
competitive in the export market. Vannoorenberghe, Wang, and Yu (2014) further argue that small exporters may have higher export volatility when they export in a more diversified pool of destinations. In addition, a lack of knowledge about foreign markets may lead the exporting firms to be more volatile.

It can be concluded that the exporting and non-exporting firms are different and might exhibit a different response to common macroeconomic shocks. Since the firms are heterogeneous (i.e; size, wages, productivity) even in a narrowly defined sector (see, for example,Bernard et al., 1995; Melitz \& Redding, 2012; Yeaple, 2005), the disaggregation of firms based on exporting nature or non-exporting nature is of a great significance.

\section{E. Sectoral Location of the Firm}

Malerba (2005) defines "sector is a set of activities which are unified by some related product groups for a given or emerging demand and which share some basic knowledge. In a sector, firms have commonalities and at the same time are heterogeneous." Further, argued that knowledge and technology, actors, and networks and institutions can be viewed as three main pillars of the sectoral system differ tremendously from sector to sector.

Since firms are located in different sectors (e.g; energy sector, chemical sector, computer sector, food sector, etc.) and these sectors have different market structure so they have to face different challenges. These firms have major differences in management, consumption for oil, supply chain, productivity, customers' base, profitability, innovation and so on and so forth. It is also recognized that firms with significantly different characteristics do coexist even in narrowly defined sectors. This implies that the firms, as well as the sectors, are heterogeneous. Several studies are supporting the argument of sectoral heterogeneity and firm heterogeneity (Elyasiani, Mansur, \& Odusami, 2013; Narayan \& Sharma, 2011). This heterogeneous nature compels the firms to respond differently to information, whether this information is firm-specific, industry-specific or market specific. Moreover, Chou et al. (2012) identified three main factors that can determine firm prospects. These factors are firmspecific characteristics, industry structure firm belongs to and state of the economy. 
Further, stated that "Firms of different industries thus may have different sensitivities to business cycles (i.e., macroeconomic factors), according to products they produce and the different stages of their industry life cycle. Returns on industry portfolios, therefore, could convey information about the state of the economy". This implies that different industries might exhibit a different level of information about the state of the economy.

It is not necessary that investors possess information about all the firms located in each sector in the market. The information processing capacity for asset prices thus may vary from one sector to the other sector. Merton (1987) argue that investors never have information about all the stocks traded in the market, therefore there holding of stocks is limited, depending upon the information they possess. This implies that the investors may pay more attention to some sectors and ignore others because of limited resources and less ability to interpret the available information. This also suggests that investors may have more access to the information for some sectors than the other sectors. Moreover, Hong and Stein (1999) proposed the gradual diffusion of information to investors. Furthermore, the traders are bounded rational which means that they are lacking the ability to process all available public information and can only process a small portion. Hence, stock prices slowly adjust to new information causing under-reaction. Hong, Torous, and Valkanov (2007) further supporting the argument of the limited processing capacity of investors by suggesting two reasons. (i) many investors pay limited attention to information (ii) investors are not specialist of all markets, so they only extract information from those markets in which they are specialized. This behaviour of investors will ultimately affect the stock prices of sectors differently. Narayan and Sharma (2011) explained that stock prices might affect differently in different sectors because of their unique market structure and heterogeneous nature.

Moreover, Hou and Robinson (2006) draw attention to the industry market structure that may affect the risk of firms' cash flows and consequently affect the firms' profitability. Further argued that firms in highly concentrated industries are less exposed to distress risk than the firms in other industries. The reason might be the entry 
barriers to highly concentrated industries. This also allows the firm to be less innovative and consequently reduces the fire risk. This implies that firms engage in more innovation activities are riskier. The innovation activities may also differ from sector to sector depending on the sectoral demand to be more competitive in the market.

The arguments presented above explain the sectoral heterogeneity and firm heterogeneity, Sharma et al. (2014) also strengthened this argument by providing empirical evidence for the US sectors heterogeneity. These arguments presented above and the empirical evidence suggested the importance of firm-level study considering the sectoral location of firms. Elyasiani et al. (2013) also emphasized the importance of studying sectoral level volatility as it will be helpful for the investors to achieve optimal portfolio selection and manage risk effectively. Hence, a firm level study will be more helpful to understand firms' response to changes in the economic factors located in different sectors.

\section{Conclusion}

It is evident from the literature survey that the firm-level volatility was not given much attention compared to the aggregate stock market volatility and the sectoral level volatility. Surprisingly, the studies in the context of firm-level volatility are scarce up till now (Sharma et al., 2014). Further, the results obtained from the hypothesis testing considering the homogeneous behaviour of firms at aggregate market level and the sectoral level analysis are spurious (Narayan \& Sharma, 2011; Sharma \& Narayan, 2014). Moreover, the firms can be categorized according to their specific characteristics such as firm size and age, firm nature of business, firm trading nature and sectoral location of the firm as its significance is proven in the literature. This categorization of firms will be helpful in explaining the heterogeneous responses of firms in the context of changes in economic factors. The theories about the firm features are also mixed and need empirical investigation. Besides, the literature has also documented that the market volatility was stable overtimes but the firm level volatility was increasing during the same time period emphasizing to study the firm level volatility (see for example; Comin and Mulani,2006; Campbell et al., 2001; Xu and Malkiel, 2003) . 
This study proposes that the linkages between the macroeconomic factors and the stock returns volatility should be studied empirically at the firm level with the perspective of the firm characteristics. This would be a significant contribution to the existing literature of finance. It is very important for the investors, portfolio managers, policy makers, and regulators to understand the behaviour of firm-level volatility with respect to macroeconomic factors considering the unique characteristics of the firm.

\section{References}

Acemoglu, D., Ozdaglar, A., \& Tahbaz-Salehi, A. (2013). The network origins of large economic downturns: National Bureau of Economic Research.

Adjasi, C. K. D. (2009). Macroeconomic uncertainty and conditional stock-price volatility in frontier African markets. The Journal of Risk Finance, 10(4), 333-349. doi: $10.1108 / 15265940910980641$

Allen, F., \& Gale, D. (2000). Financial contagion. Journal of Political Economy, 108(1), 1-33.

Allen, F., \& Santomero, A. M. (1997). The theory of financial intermediation. Journal of Banking \& Finance, 21(11), 1461-1485.

Amiti, M., \& Weinstein, D. E. (2009). Exports and financial shocks: National Bureau of Economic Research.

Augier, P., \& Dovis, M. (2013). Does export-market participation improve productivity? Evidence from Spanish manufacturing firms. The Journal of International Trade \& Economic Development, 22(7), 1059-1087.

Aw, B. Y., Roberts, M. J., \& Winston, T. (2007). Export market participation, investments in $\mathrm{R} \& \mathrm{D}$ and worker training, and the evolution of firm productivity. The World Economy, 30(1), 83-104.

Bahk, B.-H., \& Gort, M. (1993). Decomposing learning by doing in new plants. Journal of Political Economy, 561-583.

Baillie, R. T., \& DeGennaro, R. P. (1990). Stock returns and volatility. Journal of financial and Quantitative Analysis, 25(02), 203-214.

Banz, R. W. (1981). The relationship between return and market value of common stocks. Journal of financial economics, 9(1), 3-18.

Beltratti, A., \& Morana, C. (2006). Breaks and persistency: macroeconomic causes of stock market volatility. Journal of econometrics, 131(1-2), 151-177. doi: 10.1016/j.jeconom.2005.01.007

Berger, A. N., \& Udell, G. F. (1995). Relationship lending and lines of credit in small firm finance. Journal of business, 351-381.

Bernard, A. B., \& Jensen, J. B. (1999). Exceptional exporter performance: cause, effect, or both? Journal of international economics, 47(1), 1-25.

Bernard, A. B., Jensen, J. B., \& Lawrence, R. Z. (1995). Exporters, jobs, and wages in US manufacturing: 1976-1987. Brookings papers on economic activity. Microeconomics, 1995, 67-119.

Bernard, A. B., Jensen, J. B., Redding, S. J., \& Schott, P. K. (2007). Firms in international trade. The Journal of Economic Perspectives, 21(3), 105-130.

Black, F. (1976). stock market volatility changes. Proceedings of the American Statistical Association, Business and Economics Section, 177-181. 
Pakistan Journal of Humanities and Social Sciences, 7(3), 2019

Blanchard, O., \& Simon, J. (2001). The long and large decline in US output volatility. Brookings papers on economic activity, 2001(1), 135-174.

Boivin, J., \& Giannoni, M. (2002). Assessing changes in the monetary transmission mechanism: A VAR approach. Federal Reserve Bank of New York Economic Policy Review, 8(1), 97-111.

Brown, G., \& Kapadia, N. (2007). Firm-specific risk and equity market development. Journal of financial economics, 84(2), 358-388.

Buch, C. M., Döpke, J., \& Strotmann, H. (2009). Does Export Openness Increase Firm-level Output Volatility? The World Economy, 32(4), 531-551.

Campbell, J. Y., Lettau, M., Malkiel, B. G., \& Xu, Y. (2001). Have individual stocks become more volatile? An empirical exploration of idiosyncratic risk. The Journal of Finance, $56(1), 1-43$.

Cassiman, B., Golovko, E., \& Martínez-Ros, E. (2010). Innovation, exports and productivity. International Journal of Industrial Organization, 28(4), 372-376.

Chaney, T. (2016). Liquidity constrained exporters. Journal of Economic Dynamics and Control.

Chen, M.-J., \& Hambrick, D. C. (1995). Speed, stealth, and selective attack: How small firms differ from large firms in competitive behavior. Academy of management journal, 38(2), 453-482.

Chou, P.-H., Ho, P.-H., \& Ko, K.-C. (2012). Do industries matter in explaining stock returns and asset-pricing anomalies? Journal of Banking \& Finance, 36(2), 355-370.

Choudhry, T., Papadimitriou, F. I., \& Shabi, S. (2016). Stock market volatility and business cycle: Evidence from linear and nonlinear causality tests. Journal of Banking \& Finance, 66, 89-101. doi: 10.1016/j.jbankfin.2016.02.005

Christie, A. A. (1982). The stochastic behavior of common stock variances: Value, leverage and interest rate effects. Journal of financial economics, 10(4), 407-432.

Chun, Kim, J.-W., \& Morck, R. (2009). Increased Heterogeneity among US Firms: Facts and Implications: Citeseer.

Chun, H., Kim, J.-W., \& Morck, R. (2009). Increased Heterogeneity among US Firms: Facts and Implications: Citeseer.

Chun, H., Kim, J., Morck, R., \& Yeung, B. (2008). Creative destruction and firm-specific performance heterogeneity is. Journal of financial economics, 89(1), 109-135. doi: 10.1016/j.jfineco.2007.06.005

Coad, A., Segarra, A., \& Teruel, M. (2013). Like milk or wine: Does firm performance improve with age? Structural Change and Economic Dynamics, 24, 173-189.

Comin, D., \& Mulani, S. (2006). Diverging trends in aggregate and firm volatility. The Review of Economics and Statistics, 88(2), 374-383.

Comin, D., \& Mulani, S. (2009). A theory of growth and volatility at the aggregate and firm level. Journal of Monetary Economics, 56(8), 1023-1042.

Comin, D., \& Philippon, T. (2006). The rise in firm-level volatility: Causes and consequences NBER Macroeconomics Annual 2005, Volume 20 (pp. 167-228): MIT Press.

Constantinides, G. M., \& Duffie, D. (1996). Asset pricing with heterogeneous consumers. Journal of Political Economy, 219-240.

Davis, S. J., \& Kahn, J. A. (2008). Interpreting the great moderation: Changes in the volatility of economic activity at the macro and micro levels: National Bureau of Economic Research.

de Figueiredo Jr, R. J., Rawley, E., \& Rider, C. I. (2015). Why Are Firms Rigid? A General Framework and Empirical Tests. Organization Science, 26(5), 1502-1519. 
Delgado, M. A., Farinas, J. C., \& Ruano, S. (2002). Firm productivity and export markets: a non-parametric approach. Journal of international economics, 57(2), 397-422.

Drnevich, P., Marino, L., \& Withers, M. (2011). Technological Drivers of Innovation.

Elyasiani, E., Mansur, I., \& Odusami, B. (2013). Sectoral stock return sensitivity to oil price changes: a double-threshold FIGARCH model. Quantitative Finance, 13(4), 593-612. doi: 10.1080/14697688.2012.721562

Elyasiani, E., Mansur, I., \& Pagano, M. S. (2007). Convergence and risk-return linkages across financial service firms. Journal of Banking \& Finance, 31(4), 1167-1190. doi: 10.1016/j.jbankfin.2006.10.006

Engle, R. F., Ghysels, E., \& Sohn, B. (2013). Stock market volatility and macroeconomic fundamentals. Review of Economics and Statistics, 95(3), 776-797.

Evans, D. S. (1987). The relationship between firm growth, size, and age: Estimates for 100 manufacturing industries. The journal of industrial economics, 567-581.

Ewing, B. T., Kruse, J. B., \& Thompson, M. A. (2005). Comparing the Impact of News: A Tale of Three Health Care Sectors. Journal of Business Finance and Accounting,, 32(7\&8), 1587-1611.

Faulkender, M., \& Petersen, M. A. (2006). Does the source of capital affect capital structure? Review of financial studies, 19(1), 45-79.

Fort, T. C., Haltiwanger, J., Jarmin, R. S., \& Miranda, J. (2013). How firms respond to business cycles: The role of firm age and firm size. IMF Economic Review, 61(3), 520-559.

Francis, B. B., Mougoué, M., \& Panchenko, V. (2010). Is there a symmetric nonlinear causal relationship between large and small firms? Journal of Empirical Finance, 17(1), 2338.

French, K. R., Schwert, G. W., \& Stambaugh, R. F. (1987). Expected stock returns and volatility. Journal of financial economics, 19(1), 3-29.

Gal1, J., López-Salido, J. D., \& Vallés, J. (2003). Technology shocks and monetary policy: assessing the Fed's performance. Journal of Monetary Economics, 50(4), 723-743.

Girardin, E., \& Joyeux, R. (2013). Macro fundamentals as a source of stock market volatility in China: A GARCH-MIDAS approach. Economic Modelling, 34, 59-68. doi: 10.1016/j.econmod.2012.12.001

Glancey, K. (1998). Determinants of growth and profitability in small entrepreneurial firms. International Journal of Entrepreneurial Behavior \& Research, 4(1), 18-27.

Gourio, F., \& Roys, N. (2014). Size-dependent regulations, firm size distribution, and reallocation. Quantitative Economics, 5(2), 377-416.

Hagemejer, J., \& Kolasa, M. (2011). Internationalisation and Economic Performance of Enterprises: Evidence from Polish Firm-level Data. The World Economy, 34(1), 74100. doi: 10.1111/j.1467-9701.2010.01294.x

Haltiwanger, J., Jarmin, R. S., \& Miranda, J. (2013). Who creates jobs? Small versus large versus young. Review of Economics and Statistics, 95(2), 347-361.

Hannan, M. T., \& Freeman, J. (1984). Structural inertia and organizational change. American sociological review, 149-164.

Hanson, S. G., Pesaran, M. H., \& Schuermann, T. (2008). Firm heterogeneity and credit risk diversification. Journal of Empirical Finance, 15(4), 583-612.

Hong, H., \& Stein, J. C. (1999). A unified theory of underreaction, momentum trading, and overreaction in asset markets. The Journal of Finance, 54(6), 2143-2184.

Hong, H., Torous, W., \& Valkanov, R. (2007). Do industries lead stock markets? Journal of financial economics, 83(2), 367-396.

Hou, K., \& Robinson, D. T. (2006). Industry concentration and average stock returns. The Journal of Finance, 61(4), 1927-1956. 
Pakistan Journal of Humanities and Social Sciences, 7(3), 2019

Ilaboya, O. J., \& Ohiokha, I. F. (2016). Firm Age, Size and Profitability Dynamics: A Test of Learning by Doing and Structural Inertia Hypotheses. Business and Management Research, 5(1). doi: 10.5430/bmr.v5n1p29

Justiniano, A., \& Primiceri, G. E. (2006). The time varying volatility of macroeconomic fluctuations: National Bureau of Economic Research.

Kahn, J., McConnell, M. M., \& Perez-Quiros, G. (2001). Inventories and the information revolution: implications for output volatility. Federal Reserve Bank of New York Working Paper, 183-202.

Kaufman, G. G. (1994). Bank contagion: A review of the theory and evidence. Journal of Financial Services Research, 8(2), 123-150.

Khan, F., Anuar, M. A., Choo, L. G., \& Bokhari, S. A. M. (2014). Economic Exposure of Stock Returns on Karachi Stock Exchange: Substantiation from Both Aggregate and Disaggregate Data. International Journal of Information Processing and Management, $5(2), 25$.

Liljeblom, E., \& Stenius, M. (1997). Macroeconomic volatility and stock market volatility: empirical evidence on Finnish data. Applied Financial Economics, 7(4), 419-426. doi: $10.1080 / 096031097333538$

Loderer, C., Neusser, K., \& Waelchli, U. (2008). Organizational geriatrics: The fittest survive, but they wear out.

Loderer, C. F., \& Waelchli, U. (2010). Firm age and performance. Available at SSRN 1342248.

Lucas Jr, R. E. (1978). On the size distribution of business firms. The Bell Journal of Economics, 508-523.

Malerba, F. (2005). Sectoral systems of innovation: a framework for linking innovation to the knowledge base, structure and dynamics of sectors. Economics of innovation and New Technology, 14(1-2), 63-82.

Melitz, M. J., \& Redding, S. J. (2012). Heterogeneous firms and trade: National Bureau of Economic Research.

Merton, R. C. (1987). A simple model of capital market equilibrium with incomplete information. The Journal of Finance, 42(3), 483-510.

Merton, R. C. (1995). A functional perspective of financial intermediation. Financial management, 23-41.

Narayan, P. K., \& Sharma, S. S. (2011). New evidence on oil price and firm returns. Journal of Banking \& Finance, 35(12), 3253-3262. doi: 10.1016/j.jbankfin.2011.05.010

Officer, R. R. (1973). The variability of the market factor of the New York Stock Exchange. The Journal of Business, 46(3), 434-453.

Oseni, I. O., \& Nwosa, P. I. (2011). Stock market volatility and macroeconomic variables volatility in Nigeria: an exponential GARCH Approach. European Journal of Business and Management, 3(12), 43-53.

Pastor, L., \& Veronesi, P. (2003). Stock prices and IPO waves: National Bureau of Economic Research.

Petersen, M. A., \& Rajan, R. G. (1994). The benefits of lending relationships: Evidence from small business data. The Journal of Finance, 49(1), 3-37.

Pfaffermayr, M., Stöckl, M., \& Winner, H. (2013). Capital structure, corporate taxation and firm age. Fiscal Studies, 34(1), 109-135.

Poon, S., \& Taylor, S. J. (1991). Macroeconomic factors and the UK stock market. Journal of Business Finance \& Accounting, 18(5), 619-636.

Reinganum, M. R. (1981). Misspecification of capital asset pricing: Empirical anomalies based on earnings' yields and market values. Journal of financial economics, 9(1), 19-46. 
Riaño, A. (2011). Exports, investment and firm-level sales volatility. Review of World Economics, 147(4), 643-663.

Ross, S. A. (1976). The arbitrage theory of capital asset pricing. Journal of economic theory, 13(3), 341-360.

Rostamkalaei, A., \& Freel, M. (2016). The cost of growth: small firms and the pricing of bank loans. Small Business Economics, 46(2), 255-272.

Saunders, A., Cornett, M. M., \& McGraw, P. A. (2006). Financial institutions management: A risk management approach (Vol. 8): McGraw-Hill/Irwin.

Schwert, G. W. (1989). Why does stock market volatility change over time? The Journal of Finance, 44(5), 1115-1153.

Sharma, S. S., \& Narayan, P. K. (2014). New evidence on turn-of-the-month effects. Journal of International Financial Markets, Institutions and Money, 29, 92-108. doi: 10.1016/j.intfin.2013.12.002

Sharma, S. S., Narayan, P. K., \& Zheng, X. (2014). An analysis of firm and market volatility. Economic Systems, 38(2), 205-220. doi: 10.1016/j.ecosys.2013.12.003

Shleifer, A., \& Vishny, R. W. (1997). The limits of arbitrage. The Journal of Finance, 52(1), $35-55$.

Shumway, T. (2001). Forecasting bankruptcy more accurately: A simple hazard model. The Journal of Business, 74(1), 101-124.

Sims, C. A., \& Zha, T. (2002). Macroeconomic switching. manuscript, Princeton University.

Swagel, P. (2010). The Cost of the Financial Crisis: The Impact of the September 2008 Economic Collapse (pp. 1-19): The Pew Charitable Trusts.

Tarashev, N. A., Borio, C. E., \& Tsatsaronis, K. (2009). The systemic importance of financial institutions. BIS Quarterly Review, September.

Thesmar, D., \& Thoenig, M. (2011). Contrasting trends in firm volatility. American Economic Journal: Macroeconomics, 3(4), 143-180.

Thornhill, S., \& Amit, R. (2003). Learning about failure: Bankruptcy, firm age, and the resource-based view. Organization Science, 14(5), 497-509.

Vannoorenberghe, G. (2012). Firm-level volatility and exports. Journal of international economics, 86(1), 57-67.

Vannoorenberghe, G., Wang, Z., \& Yu, Z. (2014). Volatility and Diversification of Exports: Firm-Level Theory and Evidence.

Vickery, J. (2008). How and why do small firms manage interest rate risk? Journal of financial economics, 87(2), 446-470.

Vossen, R. W. (1998). Relative strengths and weaknesses of small firms in innovation. International small business journal, 16(3), 88-95.

Wagner, J. (2007). Exports and productivity: A survey of the evidence from firm-level data. The World Economy, 30(1), 60-82.

Wilson, P., \& Gorb, P. (1983). How large and small firms can grow together. Long Range Planning, 16(2), 19-27.

Xu, Y., \& Malkiel, B. G. (2003). Investigating the behavior of idiosyncratic volatility*. The Journal of Business, 76(4), 613-645.

Yeaple, S. R. (2005). A simple model of firm heterogeneity, international trade, and wages. Journal of international economics, 65(1), 1-20.

Zhou, C. (2009). Are banks too big to fail? Measuring systemic importance of financial institutions. Measuring Systemic Importance of Financial Institutions (December 1, 2009). 